\title{
Calmodulin content and activity in normal and coeliac duodenum
}

\author{
J Amoah, C Williams, R G Long
}

\begin{abstract}
Calmodulin is an important modulator of intracellular calcium processes and may be implicated in the calcium malabsorption of coeliac disease. The calmodulin content in extracts of duodenal biopsy specimens from 48 normal control subjects and 28 patients with coeliac disease was determined. Radioimmunoassay was used to measure immunoreactive calmodulin while a cyclic adenosine $3^{\prime}, 5^{\prime}$ monophosphate phosphodiesterase activity assay was used to measure biologically active calmodulin. Calmodulin values measured by both assays were similar for control and disease groups. Mean (SEM) immunoreactive calmodulin values were $1.68(0.09) \mu \mathrm{g} / \mathrm{mg}$ protein for controls and $1.67(0.15)$ and $1.45(0.15)$ $\mu \mathrm{g} / \mathrm{mg}$ protein for partial and total villous atrophy respectively. These values were not significantly different. Biologically active calmodulin values were $2.77(0.21), 1.82(0.34)$, and $3.24(0.33) \mu \mathrm{g} / \mathrm{mg}$ protein for control, partial, and total villous atrophy subjects respectively. The biologically active calmodulin values in the partial villous atrophy group were significantly lower than in controls and total villous atrophy subjects. In the phosphodiesterase assay, the calmodulin antagonist trifluoperazine inhibited the activity stimulated by purified calmodulin and by the extracts to the same extent. These results show that calmodulin values are normal in coeliac disease and provide no evidence that changes in calmodulin account for the abnormal calcium absorption in these patients.
\end{abstract}

Osteomalacia, osteoporosis, and secondary hyperparathyroidism are complications that may occur in coeliac disease because of calcium malabsorption. ${ }^{1}$ In untreated coeliac disease, the upper small intestine is characterised by villous atrophy and crypt hyperplasia with relatively immature enterocytes. ${ }^{2}$ Intestinal transcellular calcium absorption involves calcium entry at the brush border, intracellular translocation, and active transport of calcium out of the cell at the basolateral membrane. This occurs predominantly in the duodenum and upper jejunum. ${ }^{3}$

Calmodulin is a major calcium binding protein that mediates many of the intracellular actions of calcium. It is a heat stable, acidic protein with a molecular weight of 16700 Daltons and is found in all eukaryotic cells. ${ }^{3}$ Calmodulin is involved in cyclic nucleotide metabolism, hormone secretion, neurotransmitter release, cell motility, intestinal secretion, and plasma membrane calcium transport. ${ }^{45}$ In enterocytes, calmodulin is found both in the cytosol and as a structural component of the microvilli, where it is also thought to act as a calcium buffer.$^{67}$ There is conflicting evidence as to whether calmodulin is present in the basolateral membrane.$^{89}$ Jejunal calmodulin values measured by radioimmunoassay (RIA) are similar in normal subjects and in those with coeliac disease. ${ }^{6}$ However, several studies have shown that there may be differences between calmodulin, measured by RIA, and the biological activity of calmodulin, determined using a calmodulin dependent cyclic adenosine monophosphate (AMP) phosphodiesterase activity assay..$^{10-12}$ The aim of this study was to determine calmodulin values and activity in duodenal mucosa from control and coeliac subjects, since differences may partially explain the changes in calcium absorption observed in coeliac disease.

\section{Patients and methods}

\section{PATIENTS}

Biopsy specimens were obtained from the second part of the duodenum using an Olympus GIF IT endoscope with $3.7 \mathrm{~mm}$ forceps. Two specimens were placed in $10 \%$ formalin for histological assessment and others were immediately stored in liquid nitrogen.

Forty eight control subjects with normal duodenal histology undergoing investigation for diarrhoea or anaemia, or both, and 28 adult coeliac disease subjects with villous atrophy were studied. Subjects with coeliac disease were subdivided into those with partial villous atrophy (PVA) $(n=8)$ and those with subtotal villous atrophy (TVA) $(n=20)$. Two TVA patients were investigated by bone biopsy: both had histological criteria for osteomalacia and one also had osteoporosis.

\section{CALMODULIN EXTRACT PREPARATION}

One biopsy specimen from each patient was homogenised in $1.3 \mathrm{ml}$ sample buffer $(40 \mathrm{mmol} / 1$

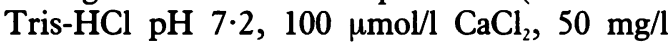
phenylmethylsulphonyl fluoride, $50 \mu \mathrm{l} / \mathrm{l}$ pepstatin A) with 30 strokes at $1200 \mathrm{rpm}$ in a Potter homogeniser at $4^{\circ} \mathrm{C} .{ }^{10}$ Aliquots were taken for total protein determination by the method of Lowry et $a l .{ }^{13}$ The homogenates were heated to $90^{\circ} \mathrm{C}$ for six minutes, rapidly cooled, and centrifuged (3000 rpm, 10 minutes). Supernatants were passed through $0.22 \mu \mathrm{M}$ sterile Millipore filters and the extracts stored in aliquots at $-70^{\circ} \mathrm{C}$.

SODIUM DODECYL SULPHATE-POLYACRYLAMIDE GEL ELECTROPHORESIS (SDS-PAGE)

Extracts of three biopsy specimens in $1.5 \mathrm{ml}$
Department of Life Sciences, Nottingham C Williams

Correspondence to: Dr R G Long, City Hospital, ottingham NG5 1 PB.

Accepted for publication 27 July 1991 
sample buffer were made using the method described above. The extracts were lyophilised and diluted in a small volume of electrophoresis sample buffer $(2 \cdot 5 \%$ sodium dodecyl sulphate, $5 \%$ 2-mercaptoethanol, $5 \%$ glycerol, $60 \mathrm{mmol} / 1$ Tris, and $0.005 \%$ bromophenol blue as a marker). Discontinuous SDS-PAGE, utilising the Laemmli methodology, was performed. ${ }^{14}$ Fifteen per cent acrylamide with 5\% cross linking slab gels were used. Thirty $\mu$ l of extracts from the three groups of subjects were applied to the gels as were pure calmodulin and molecular weight markers. The gels were stained with Coomassie blue and double stained with silver. ${ }^{15}$ The double staining procedure is a method for selectively detecting calmodulin in a mixture of proteins. ${ }^{16}$

\section{CALMODULIN ASSAYS}

\section{Radioimmunoassay of calmodulin}

The calmodulin content of the extracts was measured using a standard RIA kit (Du Pont NEN Research Products). The sensitivity of the assay kit was $0 \cdot 16 \mathrm{ng}$ and the intra- and interassay coefficients of variation were $3.42 \%$ and $8.51 \%$ respectively. The extracts were diluted with the assay buffer $(0.125 \mathrm{~mol} / 1$ borate, $\mathrm{pH}$ $8.4,0.075 \mathrm{~mol} / \mathrm{l} \mathrm{NaCl}, 0.2 \%$ bovine serum albumin, $1 \mathrm{mmol} / \mathrm{l}$ ethyleneglycol-bis (betaaminoethylether) $\mathrm{N}, \mathrm{N}, \mathrm{N}^{\prime}, \mathrm{N}^{\prime}$-tetra-acetic acid, $0 \cdot 1 \%$ sodium azide) and measured in duplicate in two assays.

\section{Cyclic AMP phosphodiesterase activity assay of calmodulin}

This assay measured biological calmodulin activity in the extracts by detecting the conversion of $\left[{ }^{3} \mathrm{H}\right]$ cyclic adenosine $3^{\prime}, 5^{\prime}-$ monophosphate to [ $\left.{ }^{3} \mathrm{H}\right] 5^{\prime}$ adenosine monophosphate by calmodulin stimulated cyclic adenosine 3', 5'- monophosphate phosphodiesterase. The resultant $\left[{ }^{3} \mathrm{H}\right] 5^{\prime}$ adenosine monophosphate was converted by Crotalus atrox snake venom (a source of $5^{\prime}$ nucleotidase) to $\left[{ }^{3} \mathrm{H}\right]$ adenosine and inorganic phosphate. The $\left[{ }^{3} \mathrm{H}\right]$ adenosine was separated with anion exchange resin (Dowex AGIX 8) and quantified by liquid scintillation counting. The methodology has previously been described by MacNeil et al. ${ }^{17}$

The final reaction volume was $400 \mu \mathrm{l}$ and contained $40 \mathrm{mmol} / 1 \mathrm{Tris}-\mathrm{HCl}, \mathrm{pH} 7 \cdot 2,4 \mathrm{mmol} / 1$ 2-mercaptoethanol, $25 \mu \mathrm{mol} / 1 \mathrm{CaCl}_{2}, 5 \mathrm{mmol} / \mathrm{l}$ $\mathrm{MgCl}_{2}$, and $100 \mu \mathrm{mol} / \mathrm{l}$ cyclic adenosine $3^{\prime}, 5^{\prime}$ monophosphate with $1 \times 10^{5} \mathrm{cpm}\left[{ }^{3} \mathrm{H}\right]$ cyclic adenosine $3^{\prime}, 5^{\prime}$-monophosphate/tube and $100 \mu \mathrm{l}$ diluted extract or various dilutions of purified bovine brain calmodulin. Extracts were measured in triplicate in two assays.

\section{Calmodulin antagonist}

Trifluoperazine is a phenothiazine antipsychotic drug that is commonly used to investigate calmodulin dependent cellular processes. ${ }^{5}$ Calmodulin antagonism by trifluoperazine was used to inhibit the phosphodiesterase activity stimulated by extracts. Final assay concentrations of $9 \mu \mathrm{mol} / \mathrm{l}$ and $90 \mu \mathrm{mol} / 1$ trifluoperazine in $10 \%$ dimethylsulphoxide (DMSO) or $10 \%$ DMSO only as control were added to normal histology $(n=14)$, partial villous atrophy $(n=4)$, and total villous atrophy $(n=9)$ extracts and to pure calmodulin $(n=3)$. The final DMSO concentration was $0 \cdot 25 \%$.

\section{STATISTICS}

Data are presented as mean (SEM). Comparison between the different groups of patients was analysed by Mann-Whitney U test for unpaired data.

\section{CHEMICALS}

Calmodulin deficient beef heart cyclic adenosine 3',5'-monophosphate phosphodiesterase was purchased from Boehringer Mannheim, London. [ $\left.{ }^{3} \mathrm{H}\right]$ cyclic adenosine $3^{\prime}, 5^{\prime}$-monophosphate and purified bovine brain calmodulin were from Amersham Int plc, Amersham. All other chemicals were from Sigma Co Ltd, Dorset.

\section{Results}

On SDS-PAGE the extracts showed several bands, including a definite band that ran identically with purified calmodulin and gave an apparent molecular weight of approximately 16600 Dalton. In all the extracts tested the 'calmodulin' band remained blue on double staining with silver. The double staining procedure is a method for selectively detecting calmodulin in a mixture of proteins. ${ }^{16}$

In both RIA and phosphodiesterase assays the extracts diluted in parallel with pure calmodulin. The calmodulin values measured by RIA were $1.68(0.09), 1.67(0.15)$, and $1.45(0.15) \mu \mathrm{g}$ calmodulin/mg protein for normal duodenal histology, partial villous atrophy, and subtotal villous atrophy groups respectively. These differences were not statistically significant ( $>0.05$ ) (Fig 1). Aliquots of the same extracts measured by phosphodiesterase activity assay gave values of $2.77(0.21), 1 \cdot 82(0.34)$, and 3.24 $(0.33) \mu \mathrm{g}$ calmodulin/mg protein for normal duodenal histology, partial villous atrophy, and subtotal villous atrophy groups. The partial villous atrophy value was statistically significant when compared with both normal duodenal histology $(\mathrm{p}=0.026)$ and subtotal villous atrophy $(p=0.020)$ (Fig 2). The difference between normal duodenal histology and subtotal villous atrophy was not significant $(p>0.05)$. The subject with osteomalacia only had an immunoreactive calmodulin value of $1.33 \mu \mathrm{g} / \mathrm{mg}$ protein and $3.45 \mu \mathrm{g} / \mathrm{mg}$ protein of biologically active calmodulin. The corresponding values for the subject who also had osteoporosis were 1.13 and $6.88 \mu \mathrm{g}$ calmodulin $/ \mathrm{mg}$ protein. The mean biologically active calmodulin values of the extracts to which the antagonist had been added were $3.13(0.35)$ for normal duodenal histology $(n=14), 2 \cdot 47(0.47)$ for partial villous atrophy $(\mathrm{n}=4)$, and $3.82(0.26) \mu \mathrm{g}$ calmodulin/mg protein for subtotal villous atrophy $(n=8)$. With 9 and $90 \mu \mathrm{mol} / 1$ trifluoperazine, phosphodiesterase activity stimulated by pure calmodulin and by the extracts from all three groups was inhibited to 


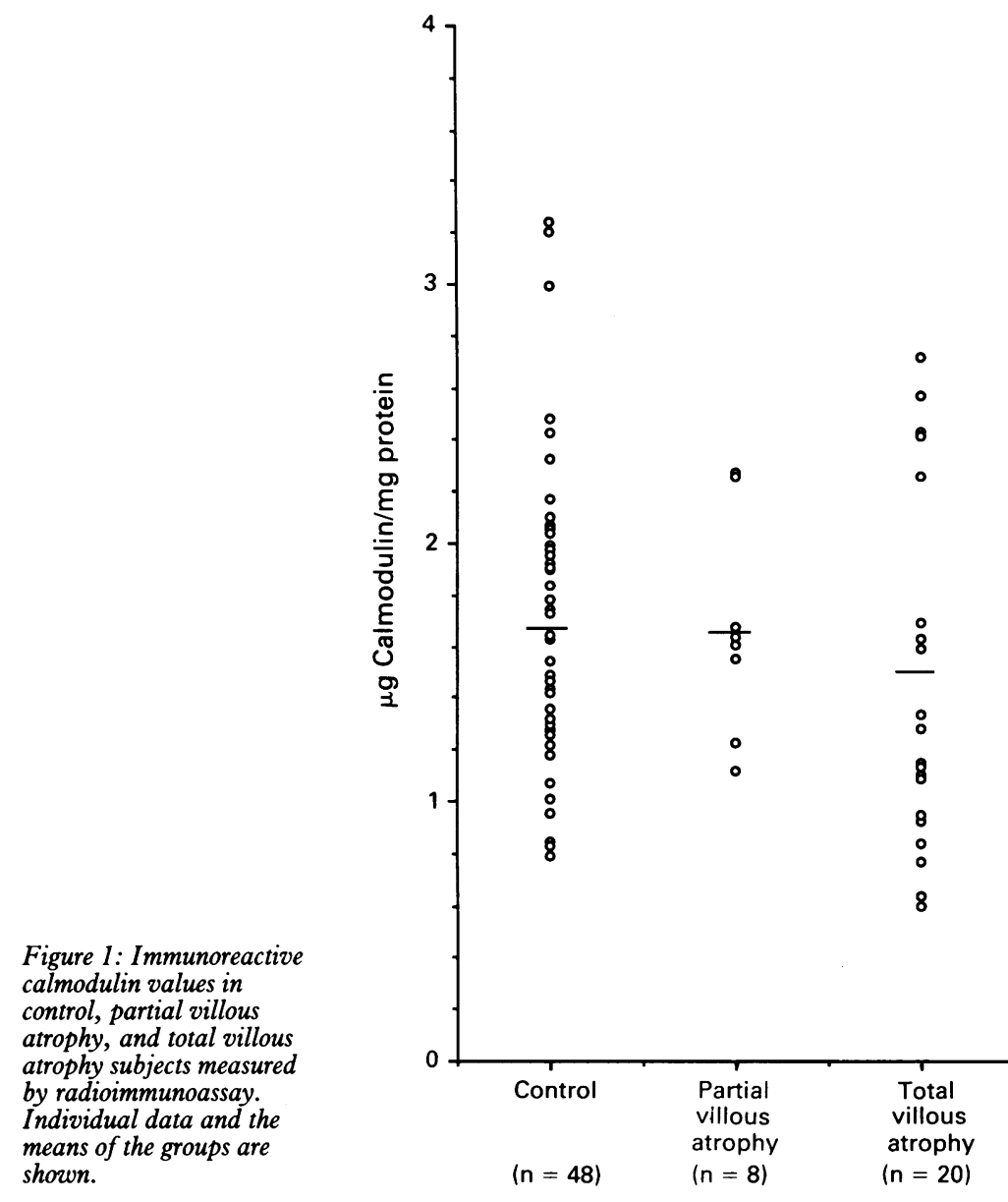

a similar extent (Fig 3). The trifluoperazine results added further evidence that the phosphodiesterase stimulation by the extracts was due to the presence of calmodulin.

\section{Discussion}

In this study, the presence of calmodulin in heat treated extracts of normal and coeliac disease duodenal biopsy specimens was shown by the inhibition of calmodulin stimulated phosphodiesterase activity and the staining characteristics of the 'calmodulin' bands in the extracts which were comparable with pure calmodulin. Control subjects and those with coeliac disease, both partial villous atrophy and subtotal villous atrophy, had similar concentrations of immunoreactive calmodulin. The latter finding is consistent with the work of McPherson et al, who found no difference between jejunal immunoreactive calmodulin values in coeliac disease in relapse or remission and controls. ${ }^{6}$

Calmodulin is a major calcium binding protein that modulates many calcium dependent cellular processes. In the small intestine, the calcium/ calmodulin complex is involved in the regulation of intracellular coupled $\mathrm{NaCl}$ transport across the rabbit microvillus membrane. ${ }^{18}$ Calcium uptake by human brush border membrane vesicles is reduced in the presence of calmodulin inhibitors. ${ }^{9}$ ATP-dependent calcium transport is stimulated by calmodulin in both rat and

Figure 2: Biologically active calmodulin values in control, partial villous atrophy, and total villous atrophy subjects. Individual data and the means of the groups are shown. The difference between means for partial villous atrophy and normal histology is statistically significant, $p=0 \cdot 026$. Partial villous atrophy $v$ total villous atrophy is also significant, $p=0 \cdot 020$.

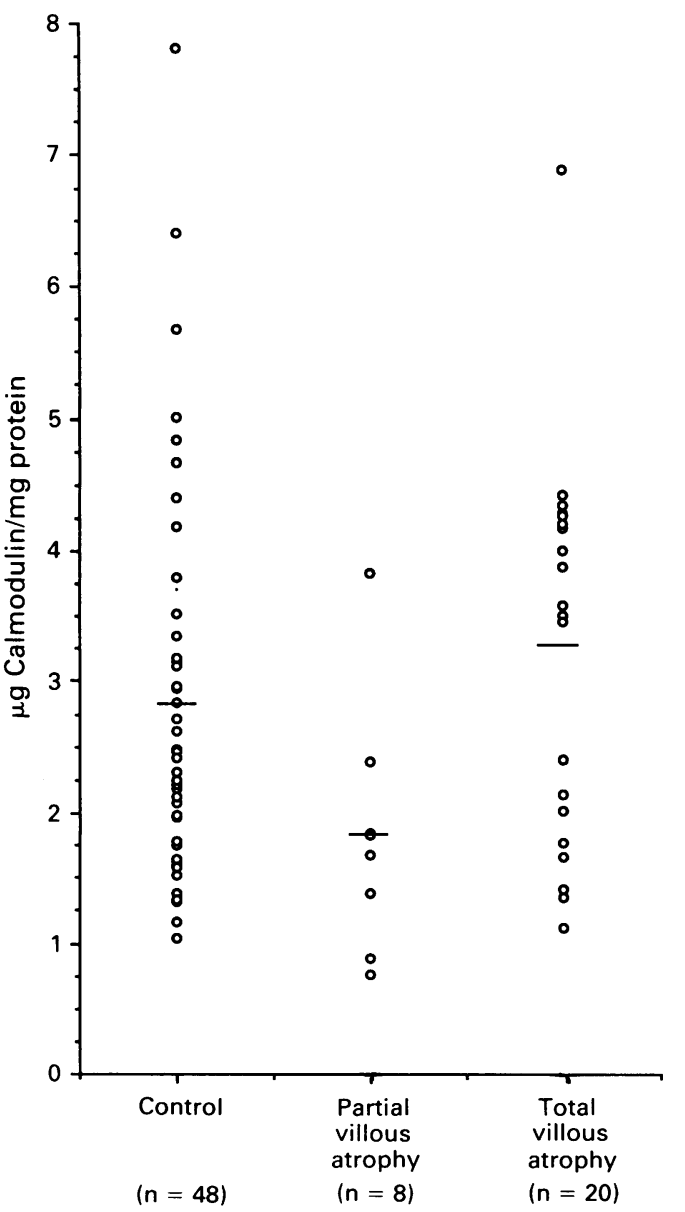

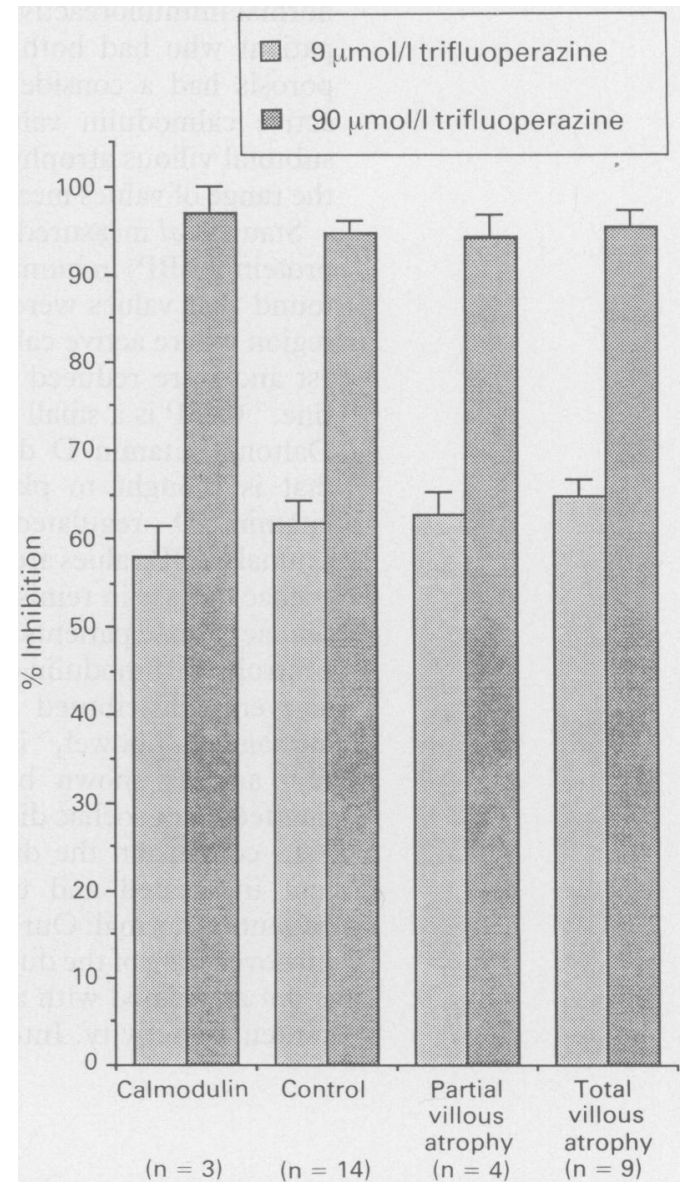

Figure 3: The percentage inhibition (mean (SEM)) by trifluoperazine of phosphodiesterase activity stimulated by pure calmodulin and by extracts from control, partial villous atrophy, and total villous atrophy subjects. 
human basolateral membrane preparations. ${ }^{1920}$ Calmodulin might therefore be implicated in the calcium malabsorption associated with coeliac disease that can lead to osteomalacia, osteoporosis, and secondary hyperparathyroidism.

Calmodulin has also been shown to be important in DNA synthesis and cellular proliferation in several tissues. ${ }^{21}$ In hyperproliferative tissue, such as the skin in psoriasis, both the immunoreactive calmodulin content and calmodulin activity measured by phosphodiesterase assay are raised. ${ }^{10}$ It could be hypothesised that the crypt hyperplasia and increased cell turnover associated with coeliac disease leads to an increase in calmodulin content. Our results do not support this hypothesis. Biologically active calmodulin values were similar in control and subtotal villous atrophy subjects, and in contrast to the immunoreactive values, were reduced in subjects with partial villous atrophy. In a study on submandibular glands from patients with cystic fibrosis, biologically active calmodulin values were raised in the disease group while immunoreactive values were not. The difference was attributed to the presence of a regulator of calmodulin activity. ${ }^{11}$ This is unlikely to be an explanation in this instance, as only the partial villous atrophy values were different. It is possible that since both subtotal villous atrophy and control groups show quite a wide range of interindividual variation in biologically active calmodulin values, an increased partial villous atrophy sample would have a similar larger spread. Both subjects with osteomalacia had normal immunoreactive calmodulin values. The patient who had both osteomalacia and osteoporosis had a considerably higher biologically active calmodulin value than the rest of the subtotal villous atrophy group but it was within the range of values measured in control subjects.

Staun et al measured another calcium binding protein $(\mathrm{CaBP})$ in human intestinal epithelia and found that values were highest in the proximal region where active calcium absorption is greatest and were reduced in the distal small intestine. ${ }^{22} \mathrm{CaBP}$ is a small (molecular weight 10000 Daltons) vitamin $\mathrm{D}$ dependent acidic protein, that is thought to play an important role in vitamin $\mathrm{D}$ regulated calcium absorption. ${ }^{23}$ Jejunal $\mathrm{CaBP}$ values are very low in patients with coeliac disease in remission and are negligible in coeliac disease patients in relapse compared with controls. ${ }^{24}$ Calmodulin content on the other hand is evenly distributed along the length of the human small bowel, ${ }^{25}$ is independent of vitamin $\mathrm{D},{ }^{26}$ and as shown by the present study, is unaffected in coeliac disease.

In conclusion the duodenal calmodulin content in treated and untreated coeliac disease patients is normal. Our results show that the high turnover state of the duodenum in coeliac disease is not associated with an increase in calmodulin content or activity. Intestinal calmodulin abnor- malities are not implicated in the calcium malabsorption of coeliac disease.

We are grateful to Dr D P-K Ng and Dr A S McIntyre for obtaining the biopsy specimens, to Dr I D Ansell for histological assessment and, particularly, to Dr A S McIntyre for helpful advice on the manuscript.

1 Melvin KEW, Hepner GW, Bordier P, Neale G, Joplin GF. Calcium metabolism and bone pathology in adult coeliac disease. $O$ F Med 1970; 153: 83-113.

2 Booth CC. Enterocyte in coeliac disease - 1. BMF 1970; 3: 725-31.

3 Ghishan FK, Arab N, Nylander W. Characterization of calcium uptake by brush border membrane vesicles of human small intestine. Gastroenterology 1989; 96: 122-9.

4 Tomlinson S, MacNeil S, Walker SW, Ollis CA, Merritt JE, Brown BL. Calmodulin and cell function. Clin Sci 1984; 66: 497-507.

5 MacNeil S, Griffin M, Cooke AM. Calmodulin antagonists of improved potency and specificity for use in the study of calmodulin biochemistry. Biochem Pharmacol 1988; 37: 1717-23.

6 MacPherson AJS, Bjarnason I, Peters TJ. The subcellular distribution and levels of calmodulin in jejunal biopsies from control subjects and patients with coeliac disease. Clin Chim control subjects and patien
Acta 1986; 159: 133-8.

7 Glenney JR, Glenney P. Comparison of $\mathrm{Ca}^{++}$-regulated events in the small intestinal brush border. $\mathcal{F}$ Cell Biol 1985; 100: 754-63.

8 Charpin MV, Walters JF, Weiser MM. Detection of calmodulin in duodenal basolateral membrane fractions. Gastroenterology 1986; 90: 1370 [Abstract]

9 Stoll R, Stern H, Ruppin H, Domschke W. Effect of two potent calmodulin antagonists of calcium transport of brush border and basolateral vesicles from human duodenum. Aliment Pharmacol Therap 1987; 1: 415-24.

10 MacNeil S, Tucker WFG, Dawson RA, Bleehen SS, Tomlinson $\mathrm{S}$. The calmodulin content of the epidermis in psoriasis.

Clin Sci 1985; 69: 681-6.
11 Shori DK, Bradbury NA, Goodchild MC, Dormer RL, $M c$ Pherson MA. An altered calmodulin binding protein in cystic fibrosis - a clue to the biochemical defect. Clin Chim Acta 1988; 174: 283-9.

12 Wallace RW, Tallant EA, Cheung WY. Assay of calmodulin by $\mathrm{Ca}^{2+}$-dependent phosphodiesterase. In: Means AR, O'Malley B, eds. Methods in enzymology. Vol 102. New York: Academic Press, 1983: 39-47.

13 Lowry OH, Rosebrough NJ, Farr AL, Randall RJ. Protein measurement with the Folin phenol reagent. $\mathcal{F}$ Biol Chem 1951; 193: 265-75.

14 Laemmli UK. Cleavage of structural proteins during the assembly of the head of bacteriophage T4. Nature $1970 ; 227$ : $680-5$.

15 Heukeshoven J, Dernick R. Simplified method for silver staining of proteins in polyacrylamide gels and the mechstaining of proteins in polyacrylamide gels and the mech
anism of silver staining. Electrophoresis $1985 ; 6: 103-12$.

16 Rochette-Egly C. Selective detection of calmodulin in polyacrylamide gels by double staining with Coomassie Blue and silver. Electrophoresis 1984; 5: 285-8.

17 MacNeil S, Walker S, Brown BL, Tomlinson S. Evidence that calmodulin may be involved in phytohaemagglutininstimulated lymphocyte division. Biosci Rep 1982; 2: 891-7.

18 Fan C-C, Powell DW. Calcium/calmodulin inhibition of coupled $\mathrm{NaCl}$ transport in membrane vesicles from rabbit
ileal brush border. Proc Natl Acad Sci 1983; 80: 5248-52.

19 Nellans HN, Popovitch JE. Calmodulin-regulated, ATPdriven calcium transport by basolateral membranes of rat small intestine. F Biol Chem 1981; 256: 19: 9932-6.

20 Kikuchi K, Kikuchi T, Ghisan FK. Characterization of calcium transport by basolateral membrane vesicles of calcium transport by basolateral membrane vesicles

21 Veigl MI, Vanaman TC, Sedwick WD. Calcium and calmodulin in cell growth and transformation. Biochim Biophys Acta 1984; 738: $21-48$.

22 Staun $M$. Distribution of the 10000 molecular weight calcium binding protein along the small and large intestine of man. Gut 1987; 28: 878-82.

23 Wasserman RH. Molecular aspects of the intestinal absorption of calcium and phosphorus. In: DeLuca HF, Anast CS, eds. Paediatric diseases related to calcium. New York: Elsevier, 1980: 107-32.

24 Staun M, Jarnum S. Measurement of the 10000 molecular weight calcium-binding protein in small intestinal biopsy specimens from patients with malabsorption syndromes. specimens from patients with malabs
Scand $\mathcal{F}$ Gastroenterol 1988; 23: 827-32.

25 Rochette-Egly C, Lacroix B, Pfleiger H, Doffoel M, Kedinger $M$, Haffen $K$. Calmodulin in normal and cystic fibrosis intestine at different developmental stages. Gut 1988; 29: $571-9$.

26 Thomasett M, Molla A, Parkes O, Demaille JG. Intestina calmodulin and calcium binding protein differ in their distribution and in the effect of vitamin D steroids on their concentration. FEBS Letts 1981; 127: 13-6. 